\title{
The Strength of a Weak State: The Rights Revolution and the Rise of Human Resources Management Divisions
}

\section{Citation}

Dobbin, Frank, and John R. Sutton. 1998. The strength of a weak state: The rights revolution and the rise of human resources management divisions. American Journal of Sociology 104(2): 441-476.

\section{Published Version}

http://dx.doi.org/10.1086/210044

\section{Permanent link}

http://nrs.harvard.edu/urn-3:HUL.InstRepos:3322830

\section{Terms of Use}

This article was downloaded from Harvard University's DASH repository, and is made available under the terms and conditions applicable to Other Posted Material, as set forth at http:// nrs.harvard.edu/urn-3:HUL.InstRepos:dash.current.terms-of-use\#LAA

\section{Share Your Story}

The Harvard community has made this article openly available.

Please share how this access benefits you. Submit a story.

\section{Accessibility}




\title{
The Strength of a Weak State: The Rights Revolution and the Rise of Human Resources Management Divisions ${ }^{1}$
}

\author{
Frank Dobbin \\ Princeton University \\ John R. Sutton \\ University of California, Santa Barbara
}

\begin{abstract}
Since the passage of the Civil Rights Act of 1964, federal policy has revolutionized employment rights. Equal employment opportunity law, occupational safety and health legislation, and fringe benefits regulation were designed to create employee rights to equal protection, to health and safety, and to the benefits employers promise. In event-history analyses of data from 279 organizations, this research finds that these legal changes stimulated organizations to create personnel, antidiscrimination, safety, and benefits departments to manage compliance. Yet as institutionalization proceeded, middle managers came to disassociate these new offices from policy and to justify them in purely economic terms, as part of the new human resources management paradigm. This pattern is typical in the United States, where the Constitution symbolizes government rule of industry as illegitimate. It may help to explain the long absence of a theory of the state in organizational analysis and to explain a conundrum noted by state theorists: the federal state is administratively weak but normatively strong.
\end{abstract}

\section{INTRODUCTION}

How does the weak and fragmented U.S. state influence employers? Until the 1970s, sociologists tended to treat organizations as closed systems, immune from external influence. Economists were more attuned to inter-

\footnotetext{
${ }^{1}$ We thank the National Science Foundation (grant SES-8511250) for support. The first author is indebted to the Copenhagen Business School and to the Danish Social Research Council for providing a research leave. Thanks to John W. Meyer and W. Richard Scott for their collaboration on the larger project this article springs from, to Lauren Edelman and Ann Swidler for their contributions to the pilot study, and to Keith Allum, Bethany Bryson, Jessica Torres, and Roberta Stich for helping us to collect the data. Thanks to Søren Christensen, Julian Dierkes, Paul DiMaggio, Michal Frenkel, Erin Kelly, Donald Light, John W. Meyer, Morten Schmidt, Arthur Stinch-

(C) 1998 by The University of Chicago. All rights reserved. 0002-9602/99/10402-0005\$02.50
} 
organizational exchanges but treated government as a transient and usually illegitimate influence on the market. The new organizational institutionalism broke with these traditions by conceptualizing the state as an important force shaping organizations (Meyer and Rowan 1977; DiMaggio and Powell 1983). The rediscovery of the state, encouraged by a renewed emphasis on polities in other areas of sociology (Evans, Rueschemeyer, and Skocpol 1985), has had a salutary corrective effect on organizational research. Recent research shows that, in the United States, several distinct features of the federal government-its structurally limited administrative capacity, dispersal of authority across levels of government, decentralization of decision making at the national level, and ideological deference to the efficiency of the market and the natural virtues of civil society-influence how it regulates organizational life (Meyer 1983; Hamilton and Sutton 1989; Dobbin 1994). The state issues ambiguous mandates to organizations, changes rules frequently in response to protracted political negotiations and litigation, and enforces its rules in a fragmented and indecisive way. Although these features cause it to appear weak, we argue that they produce a peculiar kind of state strength. First, because the state leaves the terms of legal compliance unclear, organizations commit considerable resources to devising compliance measures. Second, because the state signals uncertainty about the legitimacy of its own authority, organizations develop rationales for those compliance solutions that locate authority in the market.

We analyze the effects of the federal employment rights revolution of the early 1970s, which revolved around equal employment opportunity (EEO), health and safety, and benefits initiatives. Previous studies have documented that EEO law was characterized by policy ambiguity and complexity, by a gradual expansion in scope, and by administrative fragmentation (Dobbin et al. 1988; Edelman 1990; Skrentny 1996). We show that these regulatory features also characterized safety and benefits initiatives and that employers responded in like ways to all three initiatives. In all three realms, the state left implementation largely to managers and experts. The uncertainties raised by legal reforms created opportunities for ambitious personnel managers to expand their purview and contributed to the rise of the human resources management (HRM) paradigm. We use retrospective data to show that these initiatives led employers to establish entire new departments dedicated to HRM, EEO, health and safety, and benefits. We show that the diffusion of these departments ac-

combe, John Skrentny, Bruce Western, James Wooten, and the AJS reviewers for suggestions. Correspondence may be directed to Frank Dobbin, Department of Sociology, Princeton University, 2-N-2 Green Hall, Princeton, New Jersey 08544-1010. E-mail: dobbin@princeton.edu 
celerated after new federal initiatives and that they appeared first in organizations that were vulnerable to governmental scrutiny.

Our central contribution is to document how the U.S. regulatory framework leads managers to recast policy-induced structures in the mold of efficiency. This is the key to the peculiar strength of America's weak state. Middle managers soon retheorized these offices with business and market rationales, describing them not as means to compliance with federal regulations but as cost-effective administrative solutions to problems of worker loyalty and productivity. As a consequence, employers continued to adopt these offices even after Reagan curtailed enforcement of the laws that had popularized them. We suggest that, in the United States, justifications for policy-induced measures drift toward efficiency in this way because constitutional constraints on federal authority symbolize government control of industry as illicit. Compliance measures are thereafter sustained not merely by ephemeral public policies but by transcendental economic laws.

Our argument engages debates about the character of the U.S. state (e.g., Skowronek 1982) and its comparative strength (e.g., Evans et al. 1985). How can the state be administratively weak but normatively strong? How, in other words, can a state with such meager administrative resources shape society so effectively? We argue that the administrative weakness of the state is the cause of its normative strength, for this weakness ensures that Americans will come to see civil society and the market as the sources of social phenomena that are in fact generated by the state. Thus, in the case at hand, constitutional restrictions on federal power that cause Congress to issue complex and ambiguous regulations, forcing employers to devise their own compliance measures, also symbolize federal rule of private enterprise as illicit, encouraging employers to invent efficiency rationales to explain those measures. The Constitution expresses the dangers of state domination of civil society and encourages Americans to see organizational practices and social customs that originate in state action as part of the natural order of things.

After sketching our conceptual argument, we chronicle how U.S. employers responded to new federal initiatives, spelling out hypotheses about where and when they responded by creating new offices. We then review alternative explanations of the creation of offices that emphasize scale economies, unionization, transaction costs, and regulatory effort. Finally, we present multivariate analyses of the diffusion of employment-related offices. We observe 279 employers, many too small to divide personnel functions. Between the mid-1960s and the mid-1980s, personnel/HRM offices doubled in popularity to $70 \%$ of the sampled employers, benefits offices doubled to $35 \%$, health and safety offices doubled to over $30 \%$, and equal employment units appeared in $40 \%$. 
American Journal of Sociology

\section{THE EMPLOYMENT RIGHTS REVOLUTION}

Since the early 1960s, much of the elaboration of human rights has taken place in the realm of employment. Congress has sought to extend rights to life and liberty (via health and safety regulation), equal protection (via equal opportunity law), and social citizenship (via regulations insuring fringe benefits) to employees. While these protections are so unevenly institutionalized that they scarcely deserve to be called rights, they nonetheless represent a dramatic change.

None of the legislation encouraged employers to establish new offices, yet, by about 1980, large employers had come to see offices of health and safety, benefits, and equal employment as imperative. These events follow a pattern found in early employment regulation. Ambiguous and complex regulations lead employers to create new departments to manage compliance, and soon, specialists promote these departments as all-purpose solutions to management problems. Conflict over the Wagner Act of 1935 led employers to establish industrial relations (IR) offices and systems, which IR specialists soon promoted for their labor management functions even to nonunion firms (Selznick 1969; Kochan, Katz, and McKersie 1986, p. 45). Complex labor controls during World War II led employers to establish bureaucratic personnel offices and systems, which personnel specialists heralded for their capacity to rationalize hiring and promotion even after wartime labor controls were removed (Baron, Dobbin, and Jennings 1986). Similarly, federal regulations of the early 1970s led employers to establish special compliance offices, which experts then promoted widely for their capacity to optimize human resources and win worker loyalty.

\section{The Character of U.S. Employment Law}

Four characteristics of U.S. employment law contributed to the pattern we describe. First, the ambiguity and complexity of compliance standards led executives to believe that they would need experts to devise management practices that would comply with the law (Edelman 1992). Ambiguity and complexity result from the weak mandate the Constitution's commerce clause gives Congress to govern private enterprise and the jurisdictional complexity caused by the separation of powers. Second, the expanding scope of the law in each realm led executives to believe that they would need permanent offices to track legal changes and devise compliance schemes. The law tends to expand because the presidential system encourages compromise legislation and because autonomous administrative and judicial branches are responsible for interpreting its meaning. Third, the fragmented nature of regulation led executives to conclude that organizations would need not merely general compliance offices but special antidiscrimination, benefits, and health and safety offices to (in the 
new jargon) "interface" with different regulatory agencies. In the United States, each organization is "likely to have officers that symbolize safety, the environment, affirmative action" to handle interactions with the fragmented bureaucracy (Meyer and Scott 1992, p. 275). Finally, antistatist elements of the state encouraged management specialists, intent on justifying their own positions, to retheorize their new offices in efficiency terms and to disassociate them from policy. The Constitution's separation of powers, dispersion of political authority to communities, and limits on federal power symbolize state domination of private enterprise as illicit and inefficient. As Jackall found in studying employer safety practices of the 1970s, "productive return is the only rationale that carries weight within the corporate hierarchy" (1983, p. 58). In consequence, the very journals that in 1975 advised executives to establish specialty offices to pursue legal compliance were by 1985 arguing that these offices helped to rationalize the management of human resources.

Professional groups were at the heart of these developments. Human resources specialists, benefits accountants, tax lawyers, safety engineers, and equal employment managers saw in employment legislation new possibilities for professional growth. They insisted to top managers that new offices could ensure legal compliance, exaggerating the risk of litigation to win organizational resources (see Edelman, Abraham, and Erlanger 1992). In recasting these departments in terms of efficiency, middle managers played to top managers' preoccupation with the bottom line and desire to avoid costs associated with legal compliance.

While we cannot undertake a comparative analysis here, we emphasize that the administratively weak U.S. state differs in significant ways from administratively strong states, among which France is often cited as the paragon. The French state differs on the four characteristics we identified. First, because its constitution does not severely limit state control of private enterprise or fully separate state powers, the French state tends to mandate substantive employment outcomes rather than creating ambiguous and complex regulations (Cummins 1986). For instance, whereas the U.S. state vaguely outlawed discrimination against the handicapped, the French state instructed employers to set aside 3\% of jobs for them (Levy 1974). As a consequence, until very recently, French firms had not developed the kinds of internal legal codes of employment that U.S. firms developed (Gavini 1997; Sutton et al. 1994). Second, because the semipresidential system creates a strong president and a unified prime minister, parliament, and administration (a "fusion of powers"), French employment laws are not typically compromise measures that undergo gradual legislative and administrative expansion after passage (Duhamel 1987; Lovecy 1992). For instance, the French state established safety standards, but it has avoided the gradual elaboration of administrative guidelines, 
covering hundreds of toxins, that occurred in the United States (Brickman and Jasanoff 1980). Third, because the state is centralized, administration of employment policy is situated in the Ministry of Labor rather than fragmented in a series of autonomous agencies (Meyer 1983). This discourages the fragmentation of the employment function within firms. Fourth, because France's constitution does not contain severe restrictions on government power, it does not symbolize state power as illicit in the way that the U.S. Constitution does (Dobbin 1994). In consequence, French managers face less pressure to recast policy-induced activities in terms of pure efficiency.

\section{ORGANIZATIONAL RESPONSE TO EEO, OSHA, AND ERISA}

From the early 1970s, management specialists argued that employers would need offices staffed by experts to comply with new laws. From the early 1980s, they borrowed rhetoric from the emerging human resources management paradigm to argue that these offices improved efficiency generally. Next, we chronicle these events to develop specific hypotheses about the effects of legal shifts, in the process considering the mediating effects of public accountability, organizational age, and employer links to professional groups. In this section, we use John Stuart Mill's (1988 [1974]) method of similarity to show that in three different policy realms, similar regulatory conditions produced similar organizational responses.

\section{The Ambiguity and Complexity of Compliance}

Compliance standards in each of these realms were ephemeral, because the law created abstract rights and proscribed various abuses rather than prescribing employer behavior. Civil Rights law established a right to nondiscrimination without specifying how that right was to be protected. Safety and health law established a right to a safe and healthy workplace and defined conditions that threatened employees but did not specify how employers should prevent these conditions. Pension reform law established a right to promised fringe benefits and complex regulations to enforce that right but did not impose a uniform structure for pensions or other benefits. Employers established specialty departments to devise compliance strategies.

Ambiguity in EEO and AA law.-In 1961, John F. Kennedy's Executive Order (EO) 10925 encouraged federal contractors to take "affirmative action" to reverse the effects of past discrimination, and in 1965, Lyndon Johnson's EO 11246 expanded the order and created the Office of Federal Contract Compliance Programs (OFCCP) to enforce it. In 1964, Title VII 
of the Civil Rights Act prohibited all private employers with 15 or more employees from discriminating on the basis of race, color, religion, sex, or national origin and created the Equal Employment Opportunity Commission (EEOC) to enforce the law (Burstein 1985; Edelman 1990).

Neither Kennedy nor Johnson defined "affirmative action" in their orders to federal contractors, and neither established practical guidelines. Likewise, Title VII made discrimination illegal but did not define it. The act appeared to cover employment practices intentionally designed to discriminate (see Shaeffer 1973, p. 65). Most employers had little idea that the law might apply to them. During the 1960s, the ambiguity of these laws caused only modest concern among employers because sanctions were rare. In the early 1970s, enforcement was increased in both realms, but little was done to clarify the terms of compliance. EEO enforcement was increased by the Equal Employment Opportunity Act of 1972, which extended coverage to very small employers and gave the EEOC power to bring lawsuits itself (Skrentny 1996, p. 127). This came in the wake of the Supreme Court's 1971 Griggs v. Duke Power decision, which ruled illegal employment tests that had a "disparate impact" on different groups absent evidence of intentional discrimination. The number of Title VII suits skyrocketed, from several hundred a year in the early 1970s to over 5,000 a year in the late 1970s (Burstein and Monaghan 1986). Employers now paid close attention to EEO law (see Petersen 1974).

The OFCCP's Order 4, revised in late 1971, expanded affirmative action coverage to small federal contractors and subcontractors. The majority of U.S. enterprises were now subject to affirmative action law-80\% according to a 1973 estimate (Stryker 1996, p. 16). The order required contractors to submit detailed statistical reports and to write annual "affirmative action programs," specifying goals and timetables (Shaeffer 1973, p. 11; Edelman 1992, p. 1537; DuRivage 1985, p. 362). Order 4 required employers to redress inequality but did not clarify how they were to do so beyond stipulating that they could not use rigid hiring quotas.

From 1972, employers were expected to invent EEO and AA compliance strategies that would stand up in court, but the courts repeatedly flip-flopped on standards of compliance. As one popular personnel management text warned, "judges interpret [EEO] law differently, and decisions are often reversed in higher courts" (Burack and Smith 1977, p. 183). Management journals extolled voluntary hiring quotas, written job tests to ensure objective selection of employees, and bureaucratic hiring and promotion systems to undermine cronyism (Dobbin et al. 1993), but the courts proved unpredictable, vacillating on the legality of hiring quotas, employment tests, and a variety of other measures. So variable was the law that the Bureau of National Affairs published the Equal Employment 
Opportunity Manual in the form of a serial (Ropp 1987). Managers devised an astonishing diversity of antidiscrimination practices-by the end of the 1970s, Kenneth Marino found 33 new practices in wide use (1980).

The continuing ambiguity of compliance standards led management writers to advocate permanent antidiscrimination offices to track legal shifts. Because the courts were so fickle, Marino (1980, p. 25) advised executives to adopt the "Good-Faith-Effort Strategy," the heart of which was a special office designed to signal that the employer was making every effort to figure out how to comply. In a Harvard Business Review article, Antonia Chayes (1974, p. 81) noted that "vigorous enforcement" had brought "serious top management attention to antidiscrimination legislation. . . . Now the penalties imposed under employment discrimination laws are seen as posing a severe financial threat." She advised executives to set up EEO and AA programs that could prevent lawsuits. Meanwhile, compensation of upper managers was being tied to affirmative action performance, and this led them to support dedicated antidiscrimination departments (Vernon-Gerstenfeld and Burke 1985, pp. 59-60; Johns and Moser 1989; Ropp 1987).

Indefinite safety and health regulations. - The Occupational Safety and Health Act of 1970 represented a revolution of sorts, for it required all employers to take steps to prevent illness and injury rather than merely making restitution after the fact through Workmen's Compensation. The act created the Occupational Safety and Health Administration (OSHA), with the power to codify safety and health regulations as they emerged in legislation, case law, and administrative law. It gave states the option of using OSHA inspectors or state safety inspectors to monitor workplaces and respond to complaints (Bardach and Kagan 1982, p. 46).

Administrative health and safety guidelines outlawed specific workplace conditions in excruciating detail rather than prescribing how to prevent those conditions, in part because the Constitution checked Congress's capacity to dictate to private enterprises. OSHA wrote countless guidelines that made particular conditions illegal but left local safety engineers to figure out how to comply. In the case of health hazards, OSHA established guidelines for exposure to hundreds of toxins. It specified acceptable levels of asbestos particulates, for instance, without dictating how factories should achieve those levels-whether by changing production techniques, installing filters, or automating work. In the case of safety hazards, OSHA established broad guidelines and encouraged plantspecific solutions. Guides to compliance, such as Richard Anderson's (1975) OSHA and Accident Control through Training, suggested that employers set up safety departments, training programs, safety committees, grievance mechanisms, and "practice" federal safety inspections (Foulkes and Morgan 1977; Ritter and Wagel 1989). 
As John Meyer and Brian Rowan argued, government safety controls "make it important for organizations to create formal safety rules, safety departments, and safety programs" to symbolize their commitment (1977, p. 350). The personnel journals suggested that such offices served a public relations function, contributing to "the appearance of social responsibility" (Mendelhoff 1979, p. 92), and could help inoculate firms against damaging legal judgments by signaling that the employer was making a "good faith effort" to comply with complex and changing regulations (Anderson 1975; Ewing 1983).

Ambiguity and complexity in benefits regulation.-The Employee Retirement Income Security Act (ERISA) of 1974 was designed to guarantee that employers would make good on pension and benefit promises. ERISA also used tax incentives to encourage employers to offer benefits democratically, to all employees. It regulated not only common retirement schemes but the whole range of employee benefits (Gill 1985, pp. 2-8). The act was a maze of esoteric legal language and was widely viewed as "the most complex piece of legislation ever passed by Congress" (Tepper 1977, p. 105). It did not dictate a universal form for pensions or other benefits, but it regulated them in fine detail. As amended through 1984, the act and its Internal Revenue Code amendments ran to 320 pages (Gill 1985). For both pension plans and benefit plans, the act established $(a)$ federal reporting requirements, $(b)$ requirements for disclosure to employees, $(c)$ fiduciary requirements, and $(d)$ investment regulations. For pension plans, the act also established $(e)$ pension plan insurance, $(f)$ eligibility and participation rules, $(g)$ vesting guidelines, and $(h)$ funding regulations (Coleman 1985).

Despite the tremendous complexity of the legislation, key stipulations remained ambiguous. The act demanded that pension plan managers exercise "fiduciary responsibility" but offered neither a definition nor a litmus test. As one primer on benefit regulation warned: "no one knows what the judicial interpretation" may be (Logue 1979, p. 65). The act required that pensions be backed by certain levels of investment, without specifying precisely how funds were to be invested. It gave employers three different sets of pension vesting guidelines to choose from. Compliance was not simply a matter of following a blueprint-it required accountants and tax attorneys who could weigh a dizzying mix of options.

While compliance standards were complex and ambiguous, the costs of noncompliance were high. Rather than requiring employers to comply, as safety and health legislation did, the act created financial incentives. First, for complying plans, employer expenses are tax deductible, employer contributions are not taxed as current income to employees, and earnings on invested funds are not taxed (Klein 1986, p. 72; Skolnik 1976). Second, the act guaranteed pensions both through insurance and with the assets of the employer, permitting employees to make claims not only 
against pension funds but also against employers. This meant that employers bore the risk of subscribing to poorly managed plans (Logue 1979, p. 62; Wooten 1994).

Employers had to rewrite virtually all pension plans and many other fringe benefit plans to comply with the new regulations (Hakala and Huggins 1976; Meyer and Fox 1974). One unanticipated consequence of the act was that thousands of small companies chose to abandon their pension plans rather than bear the costs of compliance (Davey 1978, p. 4; see also Achenbaum 1986, p. 149; Logue 1979, p. 68). Most of the rest rewrote their plans-at least 300,000 companies did so immediately (Klein and Moses 1974).

The personnel journals counseled executives to consult tax lawyers and accountants in writing plans and to establish departments to monitor plans and prepare reports for the government. A new breed of "benefits consultants" emerged to argue that experts alone could devise schemes that would guarantee tax deductions, fend off litigation, and minimize employer outlays (Meyer and Fox 1974, p. 53; Meyer 1981).

\section{The Expanding Scope of the Law}

In each realm, the scope of the law was expanded frequently via new legislation, administrative rulings, and case law. As a consequence, personnel specialists, antidiscrimination experts, safety engineers, and benefits accountants lobbied for special departments to track changes in the law and create new compliance measures.

New classes of discrimination. - Congress first expanded the scope of the Civil Rights Act in 1967, adding employees over 40 to the list of protected groups (Farley 1979, p. 12). Following the Equal Employment Opportunity Act of 1972, which signaled that the EEOC would enforce EEO law with vigor, Washington expanded the scope of the law often. In 1973, Congress required federal contractors to extend affirmative action to the handicapped, and in 1974, it required them to include Vietnam-era veterans (Pati and Adkins 1980).

Administrative and judicial rulings were responsible for much of the growth in the law. For instance, neither sexual harassment nor maternity leave were initially covered under sex discrimination law, but during the 1970 s, both the EEOC and the courts came to treat harassment and refusal to grant maternity leave as sex discrimination (Bradshaw 1987, p. 51). Sexual harassment guidelines illustrate how management specialists responded. In 1980, the EEOC issued formal guidelines that read, "Harassment on the basis of sex is a violation of Section 703 of Title VII," but offered no hints about how to prevent harassment (quoted in Spann 1990, p. 58). Key management journals-Personnel, Public Personnel 
Management, the Harvard Business Review - warned of the potential for litigation and advised managers to establish a "good faith effort" to prevent harassment by creating training programs for supervisors, hiring ombudspersons, establishing grievance mechanisms, and publishing guidelines (Spann 1990). They advised executives to establish equal employment opportunity/affirmative action (EEO/AA) offices to undertake these measures.

OSHA's growing list of dangers. - The scope of OSHA regulation expanded dramatically as a result of administrative rulings. By the late 1970s, OSHA had developed standards for some 400 dangerous substances, covering the issues of air sampling, personal protection, handling procedures, and medical exams (Northrup, Rowan, and Perry 1978, p. 49). As OSHA regulations grew, management writers implored firms to hire safety specialists. In Regulating Safety, John Mendelhoff (1979) argued that OSHA regulations had become so complex that firms could not depend on line managers for compliance. As early as 1978, a study of the chemicals and aerospace industries found that the act had caused the typical firm to create a safety department or to enlarge the existing department (Northrup et al. 1978, p. 224).

It was the instability of the law that made a safety department imperative. As Burton Malkiel argued in 1979 in the Harvard Business Review, "changing health and safety regulations" undermine corporate planning: "It is not so much the direct cost of regulation that has inhibited investment and R\&D but rather the unpredictability of regulatory changes" (1979, p. 90). Administrative and judicial decisions constantly altered the rules of the game.

The expansion of benefits regulation. - After 1974, Congress altered the tax code and amended ERISA a number of times, complicating the matter of compliance and expanding the scope of the law. Details of the tax treatment of various retirement plans were amended in new tax code legislation in 1975, 1978, 1981, 1982, and 1984 (Coleman 1985, p. 10). Each change required employers to review and rewrite their pension plans (Meyer 1981; Bixby 1986). The biggest change to ERISA came in 1980, when Congress expanded regulation of small employers, making those in shared pension plans liable for up to $100 \%$ of their assets and spurring even tiny firms to hire experts to manage pension programs (Figgie 1981).

The scope of ERISA coverage also grew for individual employers, as they switched from one-size-fits-all benefits programs to myriad pension and health insurance options and as they added such benefits as permanent disability insurance and on-site daycare. The management journals advised firms to hire full-time specialists who could design benefit plans to comply with the law and to anticipate future legal changes. For instance, as employers added $401 \mathrm{k}$ plans, benefits accountants advised them 
American Journal of Sociology

to make low-wage workers eligible, so as to ensure tax-exempt status, and to sell the plans to low-wage workers, in case the courts should decide to treat plans that discriminate de facto as taxable (Moody and Higgins 1984).

\section{The Fragmentation of Enforcement}

Enforcement of these laws was carried out by autonomous federal agencies with distinct charges. Management writers argued that all-purpose, employment-law experts would not suffice in America's fragmented regulatory environment. A 1977 article in the Harvard Business Review advised: "The various requirements of state and federal regulations ... make increasing demands on both profit and nonprofit organizations. ... Compliance with the laws relating to OSHA, EEOC, and ERISA demands expertise" (Foulkes and Morgan, p. 160).

Interfacing with the EEOC and OFCCP.-The EEOC and OFCCP were established as independent agencies to enforce EEO and AA law respectively. While nothing in the law required employers to establish antidiscrimination offices, from the early 1970s, the management journals counseled them to do so in articles with titles such as "A Total Approach to EEO Compliance" (Giblin and Ornati 1974, p. 37). Special offices could create antidiscrimination programs to preclude litigation by the EEOC and could deal with OFCCP demands for employment statistics, written affirmative action goals and timetables, and on-site "compliance reviews."

Barbara Boyle (1973, pp. 88-89) wrote in the Harvard Business Review that costly litigation made an autonomous antidiscrimination office "at the highest practicable level in the organization (i.e., outside the personnel office)" well worth the price: "The establishment of an affirmative action program is not costly-its absence is." Antonia Chayes (1974) followed with an article in the same journal, titled "Make Your EEO Program Court-Proof," that recommended naming an affirmative action officer at a minimum. A 1974 article in Personnel suggested that the law provided an opportunity to establish personnel departments and full-blown personnel systems: "Viewing the [antidiscrimination] guidelines in strictly negative terms, executives have failed to see that the government concern for programs of EEO compliance actually provides the impetus for developing a personnel system" (Froehlich and Hawyer 1974, p. 62). Employers responded by creating EEO and AA departments (Giblin and Ornati 1974, p. 45; Johns and Moser 1989, p. 56).

Interfacing with OSHA.-OSHA's powers extended beyond data collection and litigation to inspection of workplaces. The threat of inspection loomed large because OSHA regulations were already daunting and were 
proliferating quickly. As Herbert Froelich and Dennis Hawyer counseled in the journal Personnel in 1974 (p. 67): "Some years ago, a vice-president of General Motors said that 'safety is good business.' He may not have anticipated the tough regulatory crackdown of OSHA, but there is a parallel in the current government regulations: Compliance is good business." Compliance manuals suggested that employers have safety experts on hand: "An excellent person to guide the [OSHA] inspector would be the safety manager or safety engineer" (Anderson 1975, p. 243). The engineer might direct the inspector's attention to major safety innovations and away from minor technical violations (Rees 1988, p. 53). Rees found that by the mid-1980s, executives had hired safety experts with the specific goals of tracking case law and educating OSHA inspectors (1988, p. 52).

From the early 1970s, engineering journals, personnel journals, and management treatises advised that safety experts could now win permanent positions and even their own departments. The authors of a study conducted in the mid-1970s concluded: "There was general agreement among safety personnel in a broad range of firms that the passage of the Act had served to increase their own status and credibility and that of their function within the company" (Northrup et al. 1978, p. 224). The act had boosted the importance of safety units: "The net effect has been a substantial increase in the status of health and safety personnel. . . . They are regarded as necessary defenders against costly and embarrassing mistakes that threaten corporate viability" (Northrup et al. 1978, p. 49)

Interfacing with the IRS and the PBGC.-Enforcement of ERISA was divided between the Treasury Department's Internal Revenue Service (IRS), which held the authority for tax disqualification and which governed most funding issues, and the Labor Department's Pension Benefit Guarantee Corporation (PBGC), which governed fiduciary issues and handled reporting and disclosure. The PBGC demanded a range of different reports from employers, including an annual disclosure statement for each employee (Klein 1986; Coleman 1985, p. 7).

Writers in insurance and management journals argued that the paperwork alone augured well for the creation of personnel and benefits offices. ERISA and Social Security changes, a 1980 article in Personnel concluded, had boosted executive support: "Personnel activities in many organizations are becoming increasingly important-largely because of the high cost of labor and benefits [and] the negative impact of government regulations" (Zippo 1980, p. 66). As a 1977 article in the Harvard Business Review concluded, "Personnel must have the ability to understand the needs both of the line organization and of the various branches of state and federal government.... We suggest that a team be developed" that includes specialists in benefits and in the law (Foulkes and Morgan 
1977, p. 162). By failing to adhere to ERISA's complex pension guidelines, the journals pointed out, employers risked losing tax deductions for contributions, having their plans terminated by the PBGC, and being sued by current and former employees. The journals advised firms to hire benefits experts with accounting and legal backgrounds who could document compliance and make sense of emerging legal standards.

In sum, in each realm, new employment laws were ambiguous and complex, were subject to frequent expansion, and were enforced by distinct federal agencies. We hypothesize that executives responded to these laws by creating specialized departments. The journals advised employers to establish personnel offices as a first step, thus, we expect personnel offices to rise from the time of the first legislative change.

Hypothesis 1.-The Equal Employment Opportunity Act of 1972, coupled with the OFCCP's Revised Order 4 from late 1971, caused the adoption of EEO/AA offices to rise from 1972.

Hypothesis 2.-Passage of the Occupational Safety and Health Act caused the adoption of health and safety offices to rise from 1970.

Hypothesis 3.-The Pension Reform Act caused the adoption of benefits offices to rise from 1974.

HyPOTHESIS 4.-Equal employment, safety and health, and pension reform legislation caused the adoption of personnel offices to rise from 1970, when the first legislative landmark occurred.

We argue that public accountability and age should mediate the effects of legal shifts.

Public accountability and the symbolization of justice.-W. Richard Scott and John Meyer (1987) argue that public and nonprofit organizations are first to embrace new norms because they are judged more by their activities than by their performance. Marshall Meyer (1979, p. 285) adds that public organizations can more readily pass on the costs of new structures. We expect that public and nonprofit organizations will be more likely to install new offices despite the fact that government offices were exempt from many of these regulations.

Hypothesis 5.-Public and nonprofit organizations adopted new rights-related offices more readily than did private organizations.

Organizational age and institutionalization.-Stinchcombe (1965) argues that managers adopt the organizational structures prevalent at the time of the industry's birth. New organizations and industries are most likely to have the latest practices as a consequence. Studies have confirmed this and have shown that older organizations are more highly institutionalized in Selznick's (1949) sense: they are resistant to change.

НyPOTHESIS 6.-Older organizations were less likely to adopt each type of office. 
Antistatist Elements and the Reconstruction of Offices as Efficiency Centers

Middle managers initially promoted equal employment, health and safety, and benefits departments to manage legal compliance. During the late 1970s and early 1980s, however, they reconstructed these departments as components of human resources management and articulated theories of how each contributed to productive efficiency. Managers did this, we argue, because the Constitution paints state domination of private enterprise as illicit. By the time the Reagan administration cut enforcement in these three realms, the new justifications had succeeded so well that employers continued to create new departments.

Here our predictions contrast sharply with those of legal analysts who note that Reagan cut federal regulation with much fanfare and who thus predict a weakening of organizational compliance. Students of law and regulation, discussed below, suggest that compliance efforts will be proportional to the threat of regulatory sanction. Rather than declining in popularity during the early 1980s, we expect these offices to increase in popularity.

The reconstruction of the EEO/AA office as the "diversity" center.The renovation of antidiscrimination offices as efficiency centers began almost immediately. First, personnel specialists argued that formal hiring and promotion rules inspired by EEO law would not only help employers fight discrimination suits but would help them to rationalize the placement of employees. As early as 1974, Froelich and Hawyer (pp. 62-63) argued in Personnel that equal employment opportunity law had spawned performance-based personnel systems, which should be "as much a component of sound business planning as financial, manufacturing, and market planning are." By 1979, a Wall Street Journal poll of top executives found that nearly two-thirds favored government programs to increase hiring of women and minorities (Harvard Law Review 1989, p. 661). Early in the 1980s, management specialists described affirmative action practices as an "essential management tool which reinforces accountability and maximizes the utilization of the talents of [the] entire work force" (Feild 1984, p. 17). When Reagan sought to end enforcement, he encountered substantial opposition from business leaders on just these grounds (Harvard Law Review 1989).

Second, personnel specialists came to argue that diversity in the workplace increases efficiency in and of itself. From the late 1970s, management consultants extolled the secondary benefits of workforce diversity. "Leading consultants, academics and business leaders . . . point out that a well managed, diverse workforce holds potential competitive advan- 
tages for organizations" (Cox and Blake 1991, p. 45). In human resources parlance, "diversity" came to replace "affirmative action" as the code word for efforts to integrate the workforce. Proponents argued that diversity offers design, production, and marketing advantages because it brings people with varied skills and backgrounds together. In 1986, the National Association of Manufacturers described affirmative action as a "business policy which has allowed industry to benefit from new ideas, opinions and perspectives generated by greater workforce diversity" (quoted in Harvard Law Review 1989, p. 669; see also Bureau of National Affairs 1986, p. 93). We expect, following Edelman (1992), that despite Reagan's cuts in EEOC enforcement, diffusion of personnel and EEO/AA offices continued apace.

The reconstruction of health and safety as HRM and publicity functions. - Middle managers transformed OSHA-inspired safety programs into efficiency measures in three ways. First, they argued that new safety initiatives demonstrated the firm's commitment to employees, the key to winning employee commitment to the firm according to the HRM paradigm. As a popular HRM text suggested as early as 1977: "A manager can use health and safety to motivate workers" by decreasing "the sense of alienation" and increasing "identification with the organization's purposes" (Burack and Smith 1977, p. 419).

Second, during the 1970s and 1980s, executive remuneration came to be linked to stock price, causing top managers to become acutely sensitive to negative publicity. In 1983, Robert Jackall reported in the Harvard Business Review that executives believed that "the bad publicity from one serious accident in the workplace can jeopardize years of work and scores of safety awards." In the words of one high-ranking chemical company executive: "In the corporate world, 1,000 'Attaboys!' are wiped away by one 'Oh, shit!'” (Jackall 1983, p. 128). Engineers thus sold health and safety departments to executives to prevent accidents that bring negative publicity, threatening stock price, market share, and executive compensation.

Third, managers argued that new safety technologies spurred them to replace antiquated production facilities and gave them a first-mover advantage in a global economy with a growing market for safe and environmentally sound technologies. The response to OSHA's 1978 lowering of the permissible level of airborne cotton dust illustrates this point. The textile industry fought cotton dust controls designed to end brown lung disease, but the Supreme Court eventually upheld OSHA's ruling. Meanwhile, managers at one company automated cotton manufacture to reduce cotton dust exposure. They sold the changes to executives by documenting productivity gains, arguing that "OSHA's regulation on cotton dust has 
been the main factor in forcing technological innovation in a centuriesold and somewhat stagnant industry" (Jackall 1983, p. 50).

The reconstruction of benefits as the new corporate "welfare work."In the 1920s, many employers joined the "welfare work" bandwagon, convinced by arguments that generous fringe benefits could win employee commitment and undermine unionism (Brandes 1976). From the late 1970s, parallel arguments for corporate welfarism were proffered by benefits and management specialists. First, they argued that the key to winning employee commitment and solving recruitment and retention problems was to display the employer's commitment to the employee with pension, health, training, and family programs. Second, they advised that wellconceived benefit plans benchmarked to those of competitors could stem union efforts (Foulkes 1980, p. 227).

Experts clothed the new welfarism in the rhetoric of modern management, emphasizing the importance of strategic planning and integration with other management functions. One benefits textbook marveled that, "prior to the early 1980s, strategic planning [of compensation and benefits] was rare" (McCaffery 1986, p. 18). Robert Greene and Russell Roberts wrote in 1983 that sophisticated benefits packages should take employer resources into account, with an eye to "what will be required to meet the strategic goals of the organization" (p. 82). In Fred Foulkes's (1980) study of personnel and benefits systems, managers cited competitive advantage in the labor market, not legal compliance, as the key function of benefits departments. Consultants argued that a professional department charged with maximizing benefits while minimizing cost can save the employer huge sums on turnover costs, antiunion efforts, and benefits packages themselves.

We expect that despite cutbacks in federal enforcement in these three realms during the Reagan administration, which we detail below, the reconstruction of new departments in efficiency terms caused them to diffuse even after 1980.

HyPOTHESIS 7.-Despite the reduction in enforcement after 1980, the reconstruction of EEO/AA, health and safety, and benefits offices in efficiency terms caused adoption to remain high. Despite the reduction in enforcement, the rise of the human resources management paradigm caused adoption of personnel/HRM offices to remain high.

The Stages-of-Institutionalization Thesis

The reconstruction of policy-induced structures as efficient should not only cause diffusion to continue after the Reagan administration cut enforcement but should produce the pattern that Tolbert and Zucker (1983) 
discovered in the case of early civil service reforms. First, the structure is prescribed as a solution to a particular problem, whether it be a functional problem (e.g., hazardous work) or a problem of legal compliance. Next, the structure is prescribed as part of accepted management practice; "The legitimacy of the procedures themselves serves as the impetus for the late adopters" (Tolbert and Zucker 1983, p. 35). In consequence, the organizational factors that predict early adoption do not predict late adoption. We expect to find that the organizational characteristics that predict adoption of personnel, benefits, health and safety, and antidiscrimination offices will decline in importance over time, as these offices are transformed from compliance centers into productivity centers.

Hypothesis 8.-The institutionalization of personnel, EEO/AA, health and safety, and benefits units caused characteristics predicting adoption to decline in importance over time.

\section{Professionals as Agents of Diffusion}

Professional groups theorized the importance of these offices (Strang and Meyer 1994; Sutton and Dobbin 1996). Three groups were particularly important: personnel professionals, labor relations specialists, and lawyers. We argue that even loose links to such professionals should affect adoption of offices.

Personnel, labor relations, and legal offices.-A personnel office is frequently the first line of defense executives establish against employment litigation. While the personnel journals frequently advocated the creation of separate EEO, health and safety, and benefits offices as further defenses, previous studies have shown that when other factors are controlled, personnel offices are negatively associated with the creation of antidiscrimination offices (Dobbin et al. 1988; Edelman 1992). Personnel managers apparently prefer to take on new functions themselves.

HyPOTHESIS 9.-Organizations with personnel offices were less likely than others to adopt benefits, health and safety, and EEO/AA offices after legal landmarks.

Labor relations specialists, by contrast, make organizations sensitive to employment law but do not compete for resources with antidiscrimination, benefits, or health and safety offices. We expect that the presence of a labor relations unit will have a positive effect on these offices.

Нуротнеsis 10._Organizations with labor relations offices were more likely to adopt benefits, health and safety, and EEO/AA offices after legal landmarks.

Legal offices also make organizations sensitive to employment law (Sut- 
ton and Dobbin 1996), and like labor relations offices, they do not compete with the other offices.

HyPOTHESIS 11.-Organizations with legal offices were more likely to adopt benefits, health and safety, and EEO/AA offices after legal landmarks.

Weaker links to the personnel and legal professionals.-As we have seen, the journals of personnel associations, such as Personnel and Personnel Journal, actively promoted the creation of new personnel, equal employment, benefits, and health and safety positions. Other studies have found that personnel association membership increases the likelihood that an organization will adopt legal compliance measures (Dobbin et al. 1993). We expect this to hold true for HRM divisions.

HYPOTHESIS 12.-Membership in a personnel association encouraged adoption of personnel, benefits, health and safety, and EEO/AA offices after legal landmarks.

Links to labor and employment-law attorneys should have a particularly strong effect on the creation of compliance departments. We asked employers when, if ever, they kept a labor or employment-law attorney on retainer.

НуротHESIS 13._Organizations keeping a labor or employment-law attorney on retainer were more likely to create personnel, benefits, health and safety, and EEO/AA offices after legal landmarks.

\section{Labor Relations Law}

We have argued that several offices were popularized by the rights revolution of the early 1970s. But it is also possible that personnel-related offices diffused as part of a secular trend. To rule this out, we analyze labor relations offices. Between 1955 and 1985, there were no major legal reforms that might have increased their popularity. The most important federal legislation, the Landrum-Griffin Act of 1959, regulated union finances and strike activity rather than expanding union rights. The most important state legislation, "right to work" laws adopted by 20 states by the end of the 1970s, actually curtailed union rights.

НуротнESIS 14.-In the absence of landmark labor legislation, the adoption of labor relations departments did not rise significantly during the 1970s.

Two important changes in labor relations did occur, however. First, there was a general decline in unionization. Because this change occurred largely through the founding of nonunion firms in new industries, we do not expect to find that employers closed existing labor relations offices. Second, unionization grew among white collar employees in the govern- 
ment and nonprofit sectors during the 1970s. We expect that this helped to institutionalize labor relations offices. Thus, we expect to see an increase in labor relations departments in those sectors, even statistically controlling for whether the employer is unionized in the current year.

HYPOTHESIS 15.-Due to growing government and nonprofit unionization, the adoption of labor relations departments rose in those sectors during the 1970s.

Next, we review competing theories of office creation, which point to scale economies, unionism, transaction costs or labor segmentation, and regulatory effort. In the section that follows, we explore hypotheses with event-history analyses of data collected from 279 organizations for the period 1955-85.

\section{ALTERNATIVE THEORIES OF OFFICE CREATION}

Several theories offer hypotheses about where and when personnel, benefits, health and safety, equal employment, and labor relations offices will appear.

\section{Scale Economies}

In "A Formal Theory of Differentiation in Organizations," Peter Blau (1970) argues that increases in scale are accompanied by the proliferation of subunits. Blau sees increases in size leading to specialization within the organization, as in Adam Smith's celebrated pin factory, and consequently to differentiation. Blau implies that personnel administration will be differentiated from general management once the organization reaches a certain size and that functions such as benefits administration will be differentiated once the organization reaches another threshold (see also Blau and Schoenherr 1971). Empirical studies have shown a declining effect of size, represented by a logged measure.

НуротнеSIS 16.-Large organizations were more likely to install all five types of offices.

\section{Unionism}

Safety and fringe benefits are two of the pillars of union politics in the United States. Early studies of personnel practice show that unions caused employers to create new offices to deal with these issues (National Industrial Conference Board 1940). More generally, from the time of the Wagner Act, unionized firms have installed both personnel and labor relations departments to stem the growing power of unions (Jacoby 1985). 
Hypothesis 17.-Unionized organizations were more likely to adopt health and safety, benefits, personnel, and labor relations offices.

\section{Transaction Costs and Labor Segmentation Theories}

Transaction costs and labor segmentation theorists find that firms in core, capital-intensive sectors go to great lengths to secure long-term employment (Williamson 1975; Gordon, Edwards, and Reich 1982; see also Doeringer and Piore 1971). They use internal promotion systems, seniority rules, and benefits linked to job tenure, establishing personnel and benefits offices to administer these programs. They establish labor relations offices to handle unions (Jacoby 1985). They should also create safety offices to prevent accidents and equal employment offices to prevent disaffection of women and minorities. Among the 13 sectors in our sample, chemicals and electrical manufacturing are most easily classified as core. Machinery is a mixed bag, containing core firms and small machine shops (Gordon et al. 1992, pp. 199-201), but our sample probably contains few machine shops because it is limited to firms with at least 50 employees and $\$ 500,000$ in assets as of 1985 . As early as the 1940s, a similar sample of machinery firms showed a high incidence of personnel departments (Baron et al. 1986).

Hyротнеsis 18.-Organizations in the chemicals, machinery, and electrical industries were more likely to adopt all five kinds of offices.

\section{Regulatory Effort}

Students of law and regulation from both left and right agree that active enforcement and the threat of sanctions increase corporate compliance activities (Sunstein 1996; Posner 1997). Enforcement of employment law was most active during the 1970s. Ronald Reagan ran for president on a promise to reduce federal regulation of business and made good on that promise soon after taking office in 1981. Reagan officials directed the Equal Employment Opportunity Commission (EEOC) to curtail litigation and loosen standards and halved staffing at affirmative action's oversight agency, the OFCCP (Edelman 1992, p. 1541; Skrentny 1996; DuRivage 1985, p. 364). Reagan cut PBGC and Department of Labor enforcement of the Pension Reform Act, and, by cutting antitrust enforcement, he enabled firms to acquire others for the purpose of raiding their pension schemes (Achenbaum 1986, pp. 155-56). Reagan directed OSHA to curtail inspection of workplaces, to halt ongoing litigation against employers, and to reduce the number of regulated toxins (Jackall 1983; Ewing 1983; Hartnett 1996). Perhaps most important, Reagan's judicial and quasi-judicial 
appointees opposed workplace regulation and thus weakened enforcement efforts.

Нyротнеsis 19.-Employers were more likely to adopt EEO/AA, benefits, health and safety, and personnel offices in the 1970s when regulatory efforts were greatest, and they were less likely to adopt these offices from 1981, when regulatory efforts declined.

\section{DATA AND METHODS}

In the previous section, we chronicled the history of policy in three realms to show that the federal government's policy style produced a similar chain of events in each. New policies generated specialty compliance departments. Antistatist sentiments led incumbents in those departments to develop efficiency justifications for their existence. In consequence, the withdrawal of federal enforcement did not stall the diffusion of those departments. And because those departments had been theorized as enhancing efficiency in general, the factors associated with early adoption became less important over time. Next we test these claims with data from several hundred employers.

\section{The Sample}

We selected a stratified random sample of public, for-profit, and nonprofit organizations in 1985, collecting retrospective data from 279 organizations. We generated the sample in three states with different legal environments: California, New Jersey, and Virginia (Sutton et al. 1994). We sampled from 13 diverse sectors to make tests of sector effects possible.

The difficulties associated with sampling organizations have been well documented (Kalleberg et al. 1990). We sampled randomly from the best published list of organizations available for each sector. For firms in banking, chemicals, electrical manufacturing, machinery, retail trade, and transportation, we went to Dun's Million Dollar Directory, which lists all publicly traded firms with assets of $\$ 500,000$. We sampled hospitals from the directory of the American Hospital Association (1983) and nonprofits from the Encyclopedia of Associations (Akey 1984). For public organizations, we used state and federal agency directories and telephone directories to sample equal numbers of city, county, state, and federal employers. Before identifying a final sample, we contacted employers to ensure that they were located in one of the three states, operated in one of the 13 sectors, and employed at least 50 persons.

Response rate.-We contacted 620 organizations and received completed questionnaires from exactly 300 , for a response rate of $48 \%$. After follow-up telephone calls to fill in missing data, we excluded 21 organiza- 
tions due to poor data quality. This brought the survey completion rate down to $45 \%$, which compares favorably with other organizational studies: Blau and colleagues (1976) completed 36\%, Lincoln and Kalleberg (1985) completed 35\%, and Edelman (1992) completed 54\% in a telephone interview. The sample may suffer from selection bias, because organizations with personnel offices were probably more likely to respond. However, the over-time framework minimizes the problem by ensuring many cases (annual organizational spells) without personnel departments, particularly in the early years.

\section{Measurement}

Dependent variables. - We examine the creation of five structures: personnel/HRM, benefits, health and safety, EEO/AA, and labor relations. We do not distinguish between personnel and HRM departments, because they are functional equivalents. In the cases of personnel/HRM, benefits, health and safety, and labor relations, we analyze the establishment of offices.

In the case of EEO/AA, we analyze creation of either an office or an officer for several reasons. First, management journals often advocated affirmative action "officers"; whereas, they advocated benefits and health/ safety "offices" or "departments" (see Chayes 1974). Second, Edelman (1992) found that the average size of corporate affirmative action offices was less than two employees. Thus, the difference between an "office" and an "officer" is often semantic - either may involve a single expert. Third, because the average affirmative action office in a public agency has over seven employees (see Edelman 1992), we found that public employers tend to use "office" and private employers tend to use "officer."

Our data cover 1955-85. For EEO/AA office or officer, we begin the analysis in 1961, the year in which John Kennedy required "affirmative action." For other offices, which existed in some organizations before 1955, we begin the analysis in that year. For all outcomes, organizations born after 1955 enter the risk set upon birth. Organizations that abandon a particular office reenter the risk set. None of these offices was abandoned by more than a handful of employers.

Independent variables. - Table 1 lists the independent variables. All vary over time. We expect the Occupational Safety and Health Act of 1970, the Pension Reform Act of 1974, and the EEO Act of 1972 to increase the adoption of related departments. We expect these three changes to affect personnel/HRM departments from 1970, and we examine whether the diffusion of labor relations offices rises in the same year.

For each department, we start the third time period in 1981 to examine whether Reagan's cuts in enforcement stalled diffusion. If we are correct 
TABLE 1

VARIABLE LIST

\begin{tabular}{|c|c|}
\hline Variable & Definition \\
\hline Log employment ...................... & Natural logarithm of number of employees \\
\hline Union & Presence of a union contract \\
\hline Personnel/HRM office ............. & $\begin{array}{l}\text { Presence of a personnel or human resources manage- } \\
\text { ment office }\end{array}$ \\
\hline Labor relations office ............. & Presence of a labor relations office \\
\hline Personnel association . ............. & Member of a personnel association \\
\hline Age of organization ................. & Age of organization in years \\
\hline 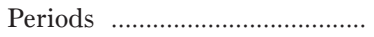 & Periods of relevant policy regimes (see text) \\
\hline Legal office $\ldots \ldots \ldots \ldots \ldots \ldots \ldots \ldots \ldots$ & Presence of a legal office \\
\hline Labor attorney on retainer .... & $\begin{array}{l}\text { Organization has a labor/employment attorney on re- } \\
\text { tainer }\end{array}$ \\
\hline \multicolumn{2}{|l|}{$\begin{array}{l}\text { Sectors:* } \\
\text { Electrical and machinery } \\
\text { Chemicals }\end{array}$} \\
\hline $\begin{array}{l}\text { Local government ............... } \\
\text { State and federal } \\
\text { Nonprofit }\end{array}$ & Includes local and county \\
\hline
\end{tabular}

in arguing that these offices had been justified in purely economic terms, the rate of adoption should not decline.

We include binary variables representing each of the sectors of theoretical interest. To operationalize transaction costs and labor segmentation theories, we include capital intensive industries with firm-specific skills: chemicals, machinery, and electrical machinery. To operationalize institutional arguments about public accountability, we include public and nonprofit sectors. To operationalize the argument that public and nonprofit unionization drives of the 1970s popularized labor relations offices there, we look at industry by period effects. With unionization controlled, public and nonprofit status should have positive effects in 1971-80. The omitted sectors are printing, transportation, trade, banking, and hospitals.

\section{The Time Trend}

Figures 1 and 2 show striking increases in the popularity of all offices but labor relations. Between 1955 and 1985, the prevalence of personnel, benefits, and health and safety offices more than doubled, with the largest gains coming after new federal employment rights were created in the early 1970s. The first EEO/AA offices and officers appeared in 1968, and, 


\section{Proportion with Personnel/HRM Office}

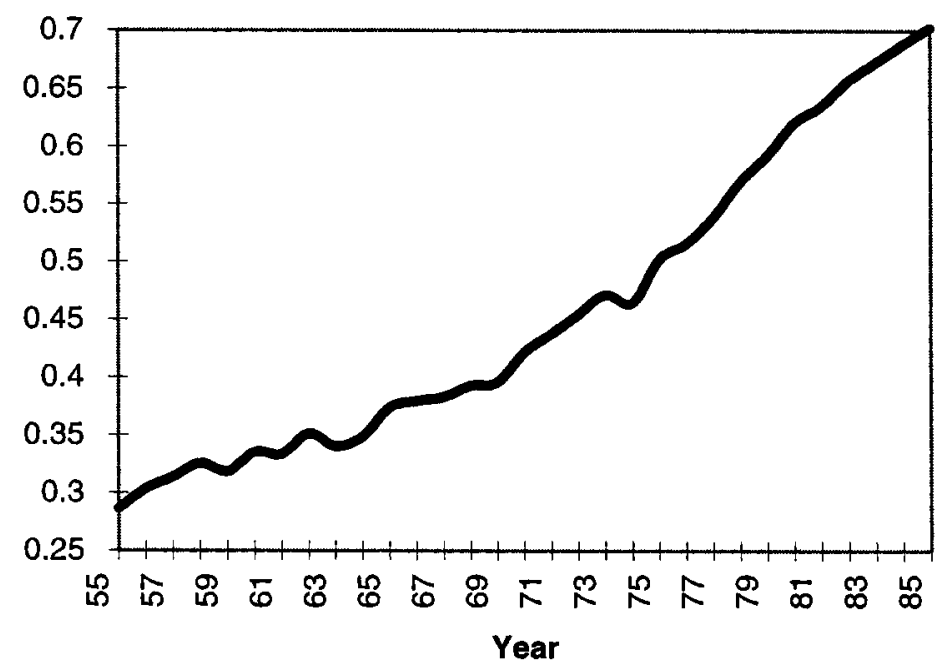

Fig. 1.-Proportion of employers with personnel/human resources office

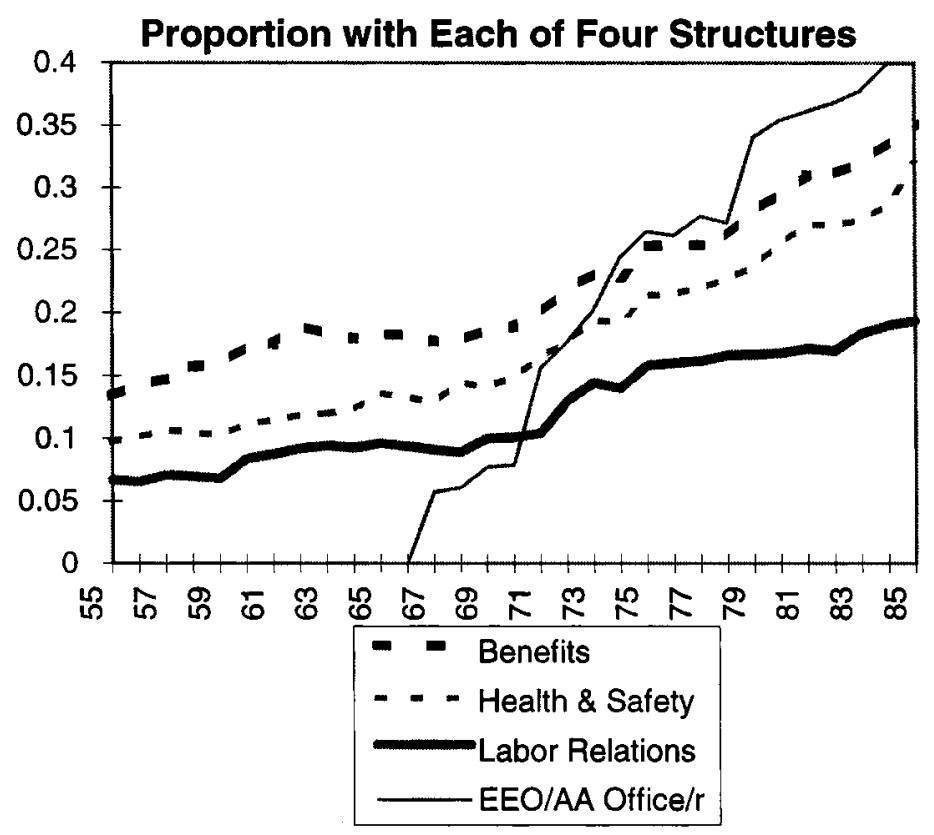

FIG. 2.-Proportion of employers with each of the four structures 
by 1985 , fully $40 \%$ of employers had them. While we can only make tentative inferences from the raw plots, they appear to support our argument about the rights revolution. For personnel, benefits, health and safety, and EEO/AA units, the slopes change notably at the end of the 1960s. For each of these, the slope does not decline after 1980, when regulatory effort declined.

\section{Estimation}

Table 2 presents piecewise exponential models, estimated with maximum likelihood techniques using Nancy Tuma's (1979) RATE program. Over the 30-year time frame we cover, the 279 organizations yield 6,701 annual spells of observation (organization-years). Organizations are excluded from the risk set before their birth and after they have adopted a practice, thus, those that had the modeled unit in 1955 are left-censored. The number of at-risk spells ranges from 3,506 to 5,779, and the number of transitions ranges from 41 to 146 .

Piecewise exponential models allow us to present a vector of variables hypothesized to have stable effects over time, constants for each time period to pick up changes in the legal environment, and interactions between time periods and other variables. To evaluate period effects, we constrained the coefficient for the constant in period 1 to equal zero.

\section{FINDINGS}

In table 2 we present one equation for each of the outcomes of interest. For comparability, we present parallel models for each of the outcomes, varying only the relevant time periods. For simplicity, we include variables that showed consistent effects across periods in the first, crossperiod, vector. We include variables that showed inconsistent effects across periods for any outcome in the time-dependent vectors.

\section{Legal Landmarks of the 1970s}

The legal changes of the early 1970s had marked effects on employers. For personnel, benefits, and EEO/AA units, the second period, representing a legal landmark, shows a significant positive coefficient. Additional support for the role of regulation is found in our analysis of labor relations offices. Was the creation of new offices simply part of a secular trend toward differentiation? There were no regulatory landmarks that might have spawned labor relations offices, and as we predicted, there is no evidence of a general rise. 
Regulatory Effort versus the Reconstruction of Departments as Efficient

The Reagan era shows a significant positive effect. Comparisons of constant terms for periods 2 and 3 show that the diffusion of personnel, benefits, health and safety, and EEO/AA offices did not slow after 1980. For three of the offices, adoption rose in the 1970s and continued at about the same rate (net of the effects of covariates) after 1980. Adoption of health and safety offices rose only after 1980 . These findings show that the weakening of regulation during the Reagan years did not slow adoption, as the regulatory effort hypothesis predicts. They support our argument that these offices had been successfully retheorized in terms of efficiency. We find not simply that existing offices survived the first Reagan term but that offices continued to be established apace.

\section{Efficiency Rationales and the Declining Importance of Covariates}

Further evidence that these offices had been retheorized in efficiency terms comes from changes in the effects of covariates. Among the four structures stimulated by the rights revolution, there is a decline over time in the importance of functional needs and susceptibility to the law. In the first period, before legal landmarks, a total of 15 coefficients for covariates are statistically significant. In the second period, a total of six are significant. In the third period, only one is significant. As these departments were reconstructed in terms of their generic efficiency, organizations of all sorts adopted them.

\section{Middle Managers as Purveyors}

We argued that professional groups promoted new offices. Having a legal office increases the chance of creating each structure in the first period and two of them in the second period. Having a labor/employment attorney on retainer shows generally positive effects. Having a labor relations office increases the chance of adopting benefits and health and safety offices, and this effect does not vary over time. Previous studies suggested that personnel managers oppose the creation of competing departments, yet above, we presented evidence that their associations promoted new positions to handle EEO, health and safety, and benefits. Accordingly, in table 2, we show that employers that belong to personnel associations are more likely to create benefits and EEO/AA units but that employers with personnel departments are no more likely to create EEO/AA and safety units and are less likely to create benefits units. 


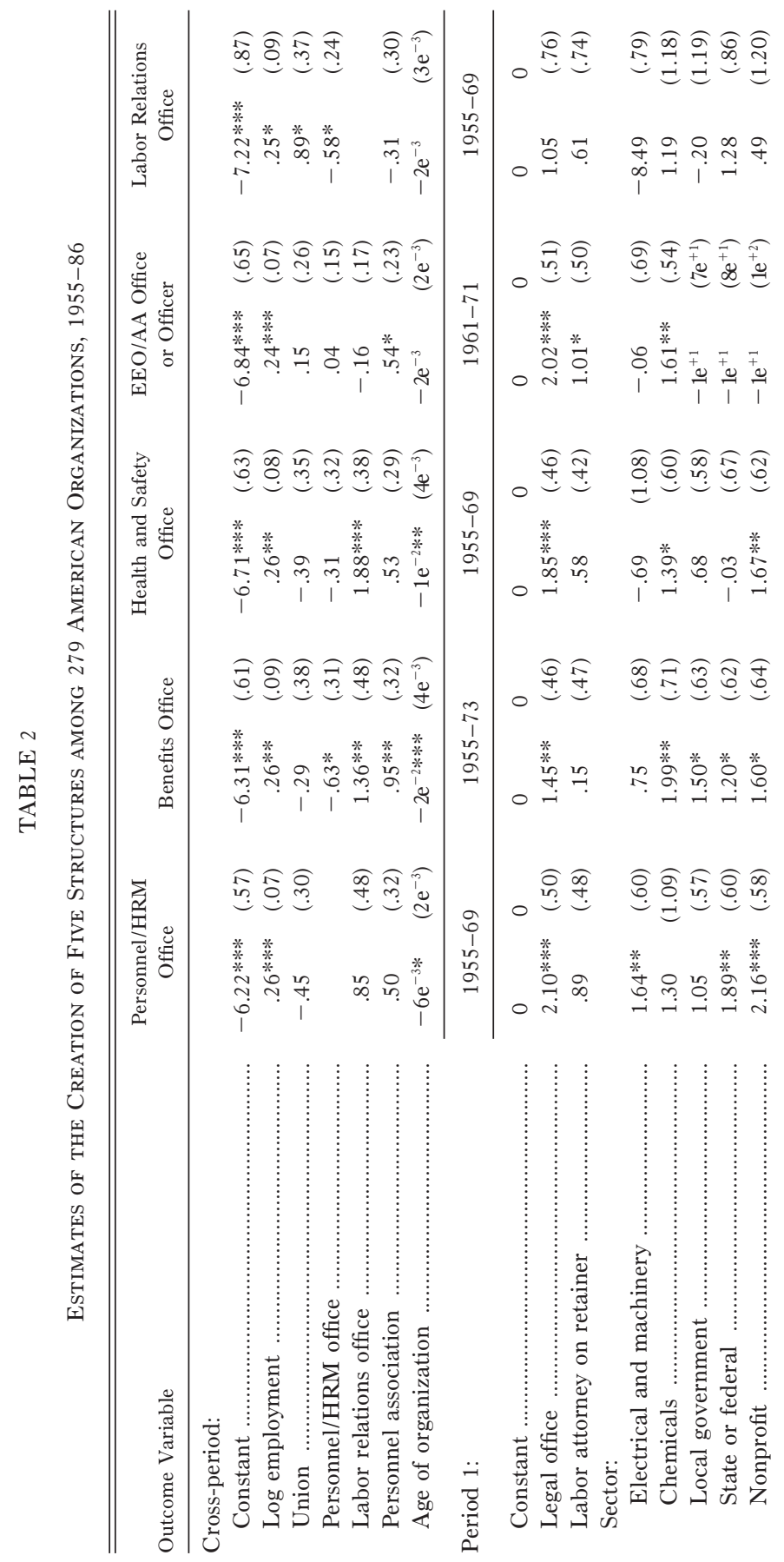




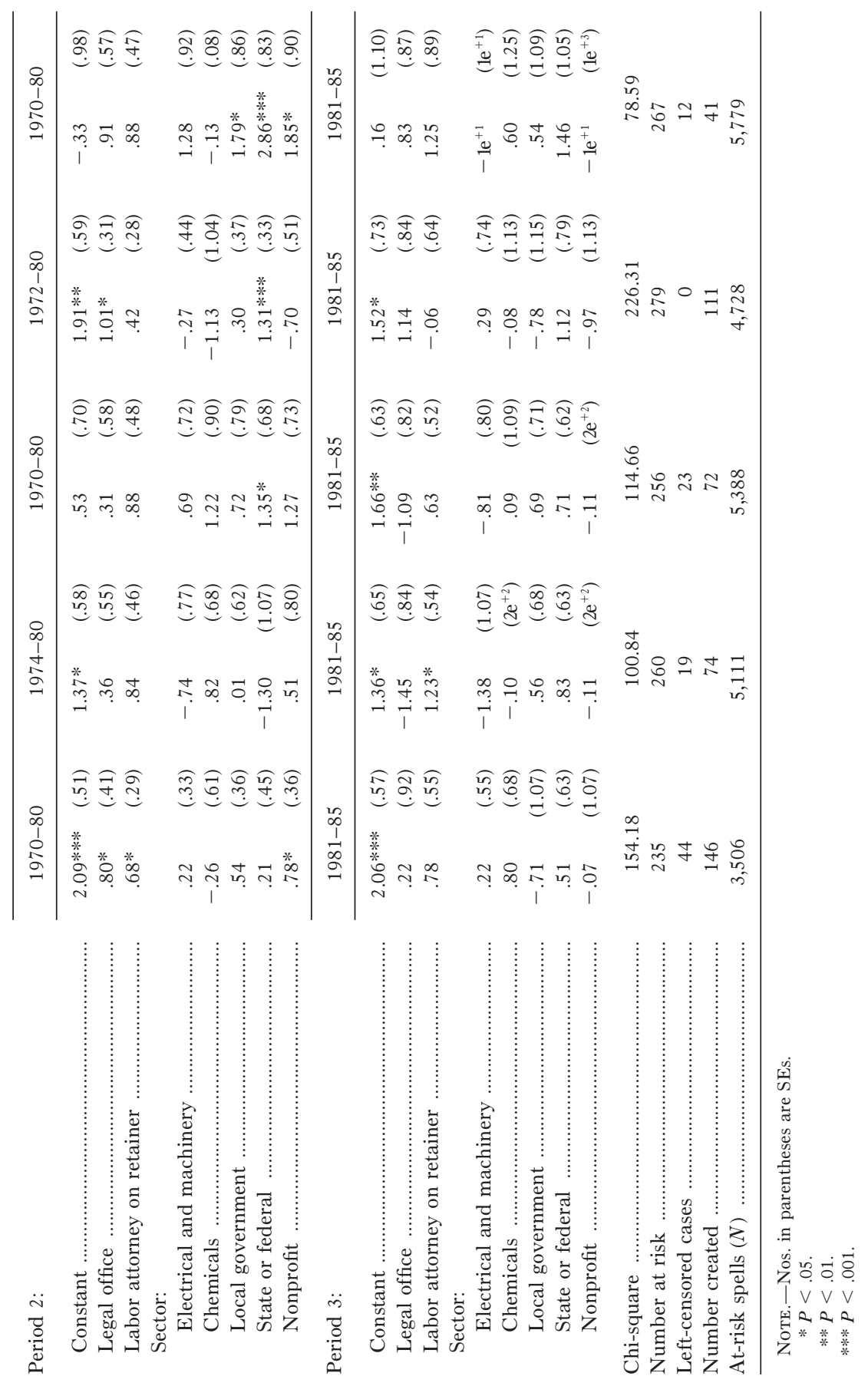


American Journal of Sociology

Age and Public Accountability

Other institutional hypotheses fare well. Older organizations are less likely to create personnel/HRM, benefits, and health and safety offices, as the Stinchcombe/Selznick hypothesis suggests. Public and nonprofit employers are more likely to adopt these same three offices before legal shifts, which suggests that they are most likely to anticipate new legal norms. After legal landmarks, public and nonprofit employers remain more likely to adopt personnel, health and safety, and EEO/AA units.

\section{Scale Economies, Unionism, Transaction Costs, and Segmentation}

The other theories show mixed results. Size, measured as log employment, shows robust effects on all five outcomes, lending support to functional arguments. The union drive of the 1970s increases labor relations offices among public and nonprofit employers, even with current union status in the equation. This can be seen in the period 2 effects of local government, state and federal government, and nonprofits on labor relations offices. The strength of these sector effects, even with establishment unionization controlled, suggests that it was not the signing of a union contract that produced new offices but wider union gains. It appears that the growth of labor relations in the 1970s, evident in figure 2, is a consequence of union gains among public and nonprofit employers alone, because the constant term for period 2 shows no effect.

Transaction costs and labor segmentation theories gain some support here. In the first period, before legal landmarks, firms in capital intensive industries that depend on firm-specific skills-electrical manufacturing, machinery, and chemicals - are more likely to install benefits, health and safety, and EEO/AA structures. This effect declines over time, however, as predicted.

\section{CONCLUSION}

The federal employment rights revolution of the early 1970s was designed to expand rights to equal protection, life and liberty, and social citizenship in the workplace. We have argued that the ambiguity of compliance standards, expanding scope of the law, and fragmentation of administration led organizations to establish specialty departments to signal a commitment to compliance, to import and invent compliance strategies, and to handle federal regulators. Organizations created new offices not because the law dictated that they do so but because the law did not tell them what to do. Management journals defined specialized offices, with expert staffs, as the best protection against costly lawsuits. Our analyses show 
that shortly after each legal landmark, employers began to create new offices to handle compliance.

The strength of the weak U.S. state is evident in what happened next. Justifications for these offices drifted away from compliance and toward pure efficiency. By 1980, managers were advocating each kind of office in the rational language offered by the new human resources management paradigm. We argue that this occurred in part because constitutional protections against the rise of federal tyranny signal that government domination of private enterprise is inefficient and illicit. It occurred in part because the law gave employers a particularly active role in devising compliance mechanisms, and hence, middle managers came to see those mechanisms as their own. And it occurred in part because ambiguous federal mandates are a thin reed on which to build elaborate new personnel programs.

It is not that managers deny that the law affects them. It is, rather, that they develop efficiency rationales for the offices they establish in response to the law. By the early 1980s, the new human resources management movement was championing diversity as the key to expanding markets and improving innovation, safety and health programs as the key to winning employee commitment and renovating antiquated technologies, and benefits programs as a means to reducing alienation and improving worker attitudes.

Our data show dramatic effects of this retheorization. When Reagan cut enforcement in 1981, the diffusion of these offices did not falter. As further evidence that departments handling benefits, health and safety, and equal employment opportunity had become disassociated from policy, over time, the policy-related covariates that predict adoption declined in importance. Whereas at first, employers with legal offices, those depending on the primary labor market, and those in public and nonprofit sectors were establishing these offices, by the 1980s, all sorts of employers were doing so.

Does this mean that the employment rights revolution has been an unmitigated success? While these offices continued to diffuse even during the Reagan years, there is evidence that cuts in enforcement led employers to circumvent the law. Employers raided pension funds in response to weakened enforcement of ERISA (Achenbaum 1986, pp. 155-56) and cut affirmative action programs in response to weakened enforcement by the OFCCP (see Bureau of National Affairs 1976, 1986). Moreover, due to the nonuniversal coverage and spotty enforcement of these laws, many workplaces continue to have few protections against discrimination, inadequate safety measures, and no pension or health coverage.

We found managers identifying market forces as the source of structures they had adopted to comply with the law, thereby reinforcing the 
authority of the market and sapping the authority of the state. This pattern helps to explain the federal government's combination of administrative weakness and normative strength, which has puzzled students of the state (e.g., Evans et al. 1985). We contend that the pattern is found in business regulation more widely, notably in antitrust law. After antitrust law forced firms to adopt new business practices, industry invented efficiency explanations for those practices. As James Q. Wilson (1980) argues, the Sherman Antitrust Act of 1890, adopted to protect the rights of small business by undermining cartels, spawned price competition. Business soon replaced the cooperative theory of the modern economy, which defined the cartels of the 1880 s as efficient, with a natural selection theory, which defined new price competition as efficient (Dobbin 1994). As Neil Fligstein (1990) argues, the Celler-Kefauver Act of 1950, adopted to undermine the power of vertically integrated firms, caused firms to expand into unrelated fields. Business soon replaced the coordination and control theory of the firm, which defined vertical links as efficient, with portfolio theory, which defined conglomeration as efficient.

This pattern, in which Americans develop collective amnesia about the state's role in shaping private enterprises, may explain the long absence of a theory of the state in organizational sociology. Americans subscribe to the theory that firms operate in a Hobbesian economic state of nature, in which behavior depends very much on managerial initiative and markets and very little on political initiative and law. We argue that this theory of the firm is a consequence of the administrative weakness of the federal state, which in the process of constructing public authority as illicit and policy as inconsequential, constructs market authority as legitimate and managers as prepotent.

\section{REFERENCES}

Achenbaum, W. Andrew. 1986. Social Security: Visions and Revisions. Cambridge: Cambridge University Press.

Akey, Denise S., ed. 1984. Encyclopedia of Associations. Detroit, Mich.: Gale Research.

American Hospital Association. 1983. Hospitals. Chicago: American Hospital Association.

Anderson, C. Richard. 1975. OSHA and Accident Control through Training. New York: Industrial Press.

Bardach, Eugene, and Robert A. Kagan. 1982. Going by the Book: The Problem of Regulatory Unreasonableness. Philadelphia: Temple University Press.

Baron, James N., Frank R. Dobbin, and P. Devereaux Jennings. 1986. "War and Peace: The Evolution of Modern Personnel Administration in U.S. Industry." American Journal of Sociology 92:350-83.

Bixby, Ann Kallman. 1986. "Social Welfare Expenditures, 1963-83." Social Security Bulletin 49:12-24. 
Blau, Peter. 1970. "A Formal Theory of Differentiation in Organizations." American Sociological Review 35:201-18.

Blau, Peter M., Cecilia McHugh Falbe, William McKinley, and Phelps K. Tracy. 1976. "Technology and Organization in Manufacturing." Administrative Science Quarterly 21:20-40.

Blau, Peter M., and Richard A. Schoenherr. 1971. The Structure of Organizations. New York: Basic.

Boyle, M. Barbara. 1973. "Equal Opportunity for Women Is Smart Business." Harvard Business Review 51:85-95.

Bradshaw, David. 1987. "Sexual Harassment: Confronting the Troublesome Issues." Harvard Business Review 32:50-52.

Brandes, Stuart D. 1976. American Welfare Capitalism, 1880-1940. Chicago: University of Chicago Press.

Brickman, Ronald, and Sheila Jasanoff. 1980. "Concepts of Risk and Safety in Toxic Substances Regulation: A Comparison of France and the U.S.” Policy Studies Journal 9:394-409.

Burack, Elmer H., and Robert D. Smith. 1977. Personnel Management: A Human Resource Systems Approach. New York: West Publishing.

Bureau of National Affairs. 1976. Equal Employment Opportunity: Programs and Results. PPF Survey no. 112. Washington, D.C.: Bureau of National Affairs.

- 1986. EEO Policies and Programs. PFF Survey no. 141. Washington, D.C.: Bureau of National Affairs.

Burstein, Paul. 1985. Discrimination, Jobs, and Politics: The Struggle for Equal Employment Opportunity in the United States since the New Deal. Chicago: University of Chicago Press.

Burstein, Paul, and Kathleen Monaghan. 1986. "Equal Employment Opportunity and the Mobilization of Law." Law and Society Review 16:355-88.

Chayes, Antonia Handler. 1974. "Make Your Equal Opportunity Program CourtProof." Harvard Business Review 52:81-89.

Coleman, Barbara J. 1985. Primer on Employee Retirement Income Security Act. Washington, D.C.: Bureau of National Affairs.

Cox, Taylor H., and Stacey Blake. 1991. "Managing Cultural Diversity: Implications for Organizational Competitiveness." Academy of Management Journal 5:45-56.

Cummins, Richard J. 1986. "The General Principles of Law, Separation of Powers, and Theories of Judicial Decision in France." International and Comparative Law Quarterly 35:592-628.

Davey, Patrick J. 1978. "Current Directions in Pension Fund Management." Conference Board Information Bulletin, no. 39. New York: Conference Board.

DiMaggio, Paul J., and Walter W. Powell. 1983. "The Iron Cage Revisited: Institutional Isomorphism and Collective Rationality in Organizational Fields." American Sociological Review 35:147-60.

Dobbin, Frank. 1994. Forging Industrial Policy: The United States, Britain, and France in the Railway Age. New York: Cambridge University Press.

Dobbin, Frank, Lauren Edelman, John W. Meyer, W. Richard Scott, and Ann Swidler. 1988. "The Expansion of Due Process in Organizations." Pp. 71-100 in Institutional Patterns and Organizations: Culture and Environment. Cambridge, Mass.: Ballinger.

Dobbin, Frank, John Sutton, John Meyer, and W. R. Scott. 1993. "Equal Opportunity Law and the Construction of Internal Labor Markets." American Journal of Sociology 99:396-427.

Doeringer, Peter B., and Michael J. Piore. 1971. Internal Labor Markets and Manpower Analysis. Lexington, Mass.: Heath.

Duhamel, Olivier. 1987. "Remarques sur la notion du régime semi-présidential." Pp. 581-90 in Droits, institutions et systèmes politiques: Mélanges en hommage à Mau- 
rice Duverger, edited by Dominique Colas and Claude Emeri. Paris: Presses Universitaires de France.

DuRivage, Virginia. 1985. "The OFCCP under the Reagan Administration: Affirmative Action in Retreat." Labor Law Journal 36:360-68.

Edelman, Lauren. 1990. "Legal Environments and Organizational Governance: The Expansion of Due Process in the American Workplace." American Journal of Sociology 95:1401-40.

_ 1992. "Legal Ambiguity and Symbolic Structures: Organizational Mediation of Civil Rights Law." American Journal of Sociology 97:1531-76.

Edelman, Lauren B., Steven E. Abraham, and Howard S. Erlanger. 1992. "Professional Construction of the Legal Environment: The Inflated Threat of Wrongful Discharge Doctrine." Law and Society Review 26:47-83.

Evans, Peter, Dietrich Rueschemeyer, and Theda Skocpol, eds. 1985. Bringing the State Back In. London: Cambridge University Press.

Ewing, David W. 1983. "Your Right to Fire." Harvard Business Review 61:32-52.

Farley, Jennie. 1979. Affirmative Action and the Woman Worker. New York: Amacom.

Feild, John. 1984. Affirmative Action: A Fresh Look at the Record Twenty-two Years after the Beginning. Washington, D.C.: Center for National Policy Review.

Figgie, Harry E., Jr. 1981. "Defusing the Pension Liability Bomb." Harvard Business Review 69:157-87.

Fligstein, Neil. 1990. The Transformation of Corporate Control. Cambridge, Mass.: Harvard University Press.

Foulkes, Fred K. 1980. Personnel Policies in Large Nonunion Companies. Englewood Cliffs, N.J.: Prentice-Hall.

Foulkes, Fred K., and Henry M. Morgan. 1977. "Organizing and Staffing the Personnel Function." Harvard Business Review 55:142-77.

Froehlich, Herbert, and Dennis Hawyer. 1974. "Compliance Spinoff: Better Personnel Systems." Personnel 51:62-69.

Gavini, Christine. 1997. "Vers un droit interne d'entreprise?" Sociologie du Travail 39:149-69.

Giblin, Edward J., and Oscar Ornati. 1974. "A Total Approach to EEO Compliance." Personnel 51:32-43.

Gill, Kathleen D. 1985. ERISA: The Law and the Code. Washington, D.C.: Bureau of National Affairs.

Gordon, David M., Richard Edwards, and Michael Reich. 1982. Seqmented Work, Divided Workers. London: Cambridge University Press.

Greene, Robert J., and Russell G. Roberts. 1983. "Strategic Integration of Compensation and Benefits." Personnel Administrator 28:82.

Hakala, Donald R., and Kenneth M. Huggins. 1976. "ERISA: Impact on Business Financial Management." Michigan Business Review 28:19-23.

Hamilton, Gary G., and John R. Sutton. 1989. "The Problem of Control in the Weak State: Domination in the United States, 1880-1920." Theory and Society 18:1-46.

Hartnett, John. 1996. OSHA in the Real World: How to Maintain Workplace Safety while Keeping Your Competitive Edge. Santa Monica, Calif.: Merritt.

Harvard Law Review. 1989. "Rethinking Weber: The Business Response to Affirmative Action." Harvard Law Review 102:658-71.

Jackall, Robert. 1983. "Moral Mazes: Bureaucracy and Managerial Work." Harvard Business Review 61:118-58.

Jacoby, Sanford. 1985. Employing Bureaucracy: Managers Unions, and the Transformation of Work in American Industry, 1900-1945. New York: Columbia University Press.

Johns, Horace, and H. Ronald Moser. 1989. "Where Has EEO Taken Personnel Policies?" Personnel 66:63-66. 
Kalleberg, Arne L., Peter V. Marsden, Howard E. Aldrich, and James W. Cassell. 1990. "Comparing Organizational Sampling Frames." Administrative Science Quarterly 35:658-88.

Klein, Alfred. 1986. "Why You Can't Afford to Ignore ERISA." Personnel Journal 65:72-83.

Klein, Michael F., Jr., and Robert H. Moses. 1974. "Pension Plans: What's at the End of the Rainbow." Price Waterhouse and Company Review 19:10-17.

Kochan, Thomas A., Harry C. Katz, and Robert B. McKersie. 1986. The Transformation of American Industrial Relations. New York: Basic Books.

Levy, Michel. 1974. "La Politique sociale francaise et les personnes handicapèes, acquis et perspectives." Analyse et Prevision 18:243-316.

Lincoln, James R., and Arne L. Kalleberg. 1985. "Work Organization and Workforce Commitment: A Study of Plants and Employees in the U.S. and Japan." American Sociological Review 50:738-60.

Logue, Dennis E. 1979. Legislative Influence on Corporate Pension Plans. Washington, D.C.: American Enterprise Institute.

Lovecy, Jill. 1992. "Comparative Politics and the Fifth French Republic: La fin de l'exception francaise." European Journal of Political Research 21:385-408.

Malkiel, Burton. 1979. "Productivity: The Problem behind the Headlines." Harvard Business Review 57:81-111.

Marino, Kenneth. 1980. "Conducting an Internal Compliance Review of Affirmative Action." Personnel 57:24-34.

McCaffery, Robert M. 1986. Employee Benefit Programs: A Total Compensation Perspective. Boston: PWS-Kent Publishing.

Mendelhoff, John. 1979. Regulating Safety. Cambridge, Mass.: MIT Press.

Meyer, John W. 1983. "Centralization of Funding and Control in Educational Governance." Pp. 179-98 in Organizational Environments: Ritual and Rationality, edited by John W. Meyer and W. Richard Scott. Beverly Hills, Calif.: Sage.

Meyer, John W., and Brian Rowan. 1977. "Institutionalized Organizations: Formal Structure as Myth and Ceremony.” American Journal of Sociology 83:34063.

Meyer, John W., and W. Richard Scott. 1992. Organizational Environments. Newbury Park, Calif.: Sage Publications.

Meyer, Marshall. 1979. "Organizational Structure as Signaling." Pacific Sociological Review 22:481-500.

Meyer, Mitchell. 1981. Profile of Employee Benefits. 1981 edition. New York: Conference Board.

Meyer, Mitchell, and Harland Fox. 1974. Profile of Employee Benefits. New York: Conference Board.

Mill, John Stuart. 1988 (1974). A System of Logic, edited by J. M. Robson. Toronto: University of Toronto Press.

Moody, Hiram F., Jr., and Edward D. Higgins. 1984. "Selling the 401(k) Plan to Employees." Harvard Business Review 62:68-78.

National Industrial Conference Board (NICB). 1940. Personnel Activities in American Business. New York: NICB.

Northrup, Herbert, Brian Rowan, and Charles Perry. 1978. The Impact of OSHA. Labor Relations and Public Policy Series, no. 17. Philadelphia: University of Pennsylvania, Wharton School, Industrial Research Unit.

Pati, Gopal C., and John I. Adkins, Jr. 1980. "Hire the Handicapped: Compliance Is Good Business." Harvard Business Review 58:14-29.

Petersen, Donald J. 1974. "The Impact of Duke Power on Testing." Personnel 51:3137.

Posner, Richard A. 1997. "The Rise and Fall of Administrative Law." Chicago-Kent Law Review 72:953-63. 
Rees, Joseph. 1988. Reforming the Workplace: A Study of Self-Regulation in Occupational Safety. Philadelphia: University of Pennsylvania Press.

Ritter, Anne, and William H. Wagel. 1989. "Special Awards for Special Achievers: Personnel Winners." Personnel 66:17-32.

Ropp, Kirland. 1987. "How the Courts Affect Management Policy." Personnel Administrator. 32:45-50, 100.

Scott, W. Richard, and John W. Meyer. 1987. "Environmental Linkages and Organizational Complexity: Public and Private Schools." Pp. 128-60 in Comparing Public and Private Schools, edited by Henry M. Levin and Tom James. New York: Falmer.

Selznick, Philip. 1949. TVA and the Grass Roots. Berkeley: University of California Press.

- 1969. Law, Society and Industrial Justice. New York: Russell Sage.

Shaeffer, Ruth G. 1973. Nondiscrimination in Employment: Changing Perspectives, 1963-1972. New York: Conference Board.

Skolnik, Alfred M. 1976. "Twenty-five Years of Employee-Benefit Plans." Social Security Bulletin 37 (3): 3-22.

Skowronek, Stephen. 1982. Building a New American State: The Expansion of National Administrative Capacities, 1877-1920. New York: Cambridge University Press.

Skrentny, John D. 1996. The Ironies of Affirmative Action: Politics, Culture, and Justice in America. Chicago: University of Chicago Press.

Spann, Jeri. 1990. "Dealing Effectively with Sexual Harassment: Some Practical Lessons from One City's Experience; Madison, Wisconsin." Public Personnel Management 19:53-82.

Stinchcombe, Arthur. 1965. "Social Structure and Organizations." Pp. 142-93 in Handbook of Organizations, edited by James March. Chicago: Rand McNally.

Strang, David, and John W. Meyer. 1994. "Institutional Conditions for Diffusion." Pp. 100-12 in Institutional Environments and Organization: Structural Complexity and Individualism. Edited by W. Richard Scott and John W. Meyer. Thousand Oaks, Calif.: Sage.

Stryker, Robin. 1996. "Law, Sociology, and Public Policy Issues in Equal Employment Opportunity." Paper presented at the annual meetings of the American Sociological Association, New York.

Sunstein, Cass R. 1996. "The APA at Fifty: Health-Health Tradeoffs." University of Chicago Law Review 63:1533-71.

Sutton, John, and Frank Dobbin. 1996. "The Two Faces of Governance: Responses to Legal Uncertainty in American Firms, 1955-1985." American Sociological Review 61:794-811.

Sutton, John, Frank Dobbin, John W. Meyer, and W. Richard Scott. 1994. "The Legalization of the Workplace." American Journal of Sociology 99:944-71.

Tepper, Irwin. 1977. "Risk vs." Harvard Business Review 55:100-115.

Tolbert, Pamela S., and Lynne G. Zucker. 1983. "Institutional Sources of Change in the Formal Structure of Organizations: The Diffusion of Civil Service Reform, 1880-1935." Administrative Science Quarterly 28:22-39.

Tuma, Nancy B. 1979. Invoking RATE. Palo Alto, Calif.: DMA Press.

Vernon-Gerstenfeld, Susan, and Edmund Burke. 1985. "Affirmative Action in Nine Large Companies: A Field Study.” Personnel 62:54-60.

Williamson, Oliver. 1975. Markets and Hierarchies: Analysis and Antitrust Implications. New York: Free Press.

Wilson, James Q., ed. 1980. The Politics of Regulation. New York: Basic.

Wooten, James A. 1994. "Regulating the 'Unseen Revolution': Private Pension Policies and Politics, 1960-1987." Working paper. SUNY-Buffalo, School of Law.

Zippo, Mary. 1980. "Roundup." Personnel 57:65-66. 